\title{
Effect of several rhizobacteria strains on barley resistance against Pyrenophora graminea under field conditions
}

\author{
A. Adam*, M.I.E. Arabi, I. Idris and E. Al-Shehadah
}

Summary The effect of Pseudomonas putida BTP1, Bacillus subtilis Bs2500, Bs2504, and Bs2508 strains on the incidence (I) and severity (S) of barley leaf stripe disease caused by Pyrenophora graminea was evaluated under field conditions. Three barley cultivars varying in resistance level were used. The resistance achieved in our study was long-lasting. P. putida BTP1 and Bs2508 were in general the most effective strains in reducing significantly both I and $S$ of barley leaf stripe disease vis-a-vis three cultivars in two growing seasons 2013/2014. The disease was reduced up to 66\% in Arabi Abiad treated with P. putida BTP1. The susceptible landrace cultivar Arabi Abiad exhibited a significant induction of resistance by Bs2508 and BTP1. However, the resistant cultivar Banteng did not exhibit significant further increase in resistance by these bacterial strains. The grain yield of bacterized plants artificially inoculated with P. graminea was not affected, except that of the cultivar Arabi Abiad treated with Bs2508 and Bs2504. Triggering of resistance by treating seeds with the bacterial strains would be of great value in agriculture, especially in case of barley infection by P. graminea at an early stage of plant development.

Additional keywords: Bacillus subtilis Bs2500, Bs2504, Bs2508, Barley leaf stripe, Pseudomonas putida BTP1

\section{Introduction}

Biological control, i.e. the use of microbial antagonists to suppress plant diseases, has gained acceptance in recent years. Among the different microbial species tested for that purpose, several aerobic sporeforming bacteria possess features that make them good candidates for use as biological control agents in the field (Sharma and Johri, 2003). Plant growth-promoting rhizobacteria (PGPR) are defined as root-colonizing bacteria with the ability to establish on or in the plant root, to propagate and to survive, exerting a beneficial effect on plant growth and development (Choudhary and Johri, 2009). Many different biological control agents have been introduced into different planting materials and can protect plants against various diseases (Bakker et al., 2007; Adam et al., 2008; Choudhary and Johri, 2009; De Vleesschauwer and Höfte, 2009; Reglinski and Walters, 2009); in partic-

Department of Molecular Biology and Biotechnology, Atomic Energy Commission of Syria (AECS), P. O. Box 6091, Damascus, Syria

* Corresponding author: ascientific1@aec.org.sy ular species belonging to the Pseudomonas and Bacillus genera have been used, relying on their different mechanisms to directly antagonize pathogen growth (Haas and Défago, 2005).

The systemic, seed-transmitted (seedborne) hemi biotrophic fungus Pyrenophora graminea Ito \& Kuribayashi [anamorph Drechslera graminea (Rabenh. ex. Schlech. Shoem.)] (Mathre, 1997) is the causal agent of leaf stripe disease in barley (Hordeum vulgare L.) which often leads to yield reductions (Porta-Puglia et al., 1986; Arabi et al., 2004). The fungus survives within the kernels as mycelium between the paranchymatical cells of the pericarp in the hull, and the seed coat but not in the embryo (Arru et al., 2002). During seed germination, the fungal hyphae begin to grow intercellularly within the coleorhiza into the embryo structures, the roots and scutellar node. The pathogen behaves as a biotroph and degrades hostcell walls using hydrolytic enzymes without causing cellular necrosis (Hammouda, 1988; Haegi et al., 2008). Once infection spreads into the young leaves, growth switches to a necrotrophic phase with the production of a host-specific glycosyl toxin (Haegi and 
Porta-Puglia, 1995) that causes longitudinally dark brown discoloration of leaves. In susceptible plants, the disease usually results in severe stunting, premature death and complete loss of grain (Tekauz and Chiko, 1980).

The vast majority of knowledge about PGPR has been gathered from studies on dicots such as cucumber, tobacco, and Arabidopsis (Ramamoorthy et al., 2001). The knowledge about induced resistance in monocots remains elusive (Van Loon, 2007; Vlot et al., 2008). The potential of PGPR to induce resistance in monocots depends on the host-PGPR combination and on the pathogen (De Vleesschauwer et al., 2006). The efficacy of PGPR in monocots against necrotrophic pathogens has been demonstrated in a few cases (Van Wees et al., 2008; Pinedra et al., 2010).

To improve the field performance and consistency of biocontrol agents against Pyrenophora graminea in barley, as a monocot crop, a deep knowledge of the physiological mechanisms on which the biological control by the known PGPR bacterial strains Pseudomonas putida BTP1and Bacillus subtilis strains Bs2500, Bs2504 and Bs2508 rely is important. The capacity of these strains to induce resistance in several pathosystems has been proved previously (Ongena et al., 2004; Ongena et al., 2007; Adam et al., 2008). The main goal of the present study was to examine the biological potential of the abovementioned four rhizobacterial strains, differing in lipopeptide production, against barley leaf stripe disease incidence and severity and also to determine their possible impact on growth and yield using three barley cultivars under field conditions.

\section{Materials and Methods}

\section{Bacterial strains and growth conditions}

The non-pathogenic rhizobacterial strain Pseudomonas putida BTP1, isolated from barley roots, was selected for use in this study as it is a strain with a pyoverdin-mediated iron system, which is regarded as an enhancer of the colonization and persistence of the strain in the rhizosphere (Ongena et al., 2002; Ongena et al., 2005). P. putida BTP1 and Bacillus subtilis Bs2508, Bs2504, and Bs2500 were kindly provided by Dr. Philippe Thonart (WalIon Center for Industrial Biology, University of Liège, Belgium). All bacterial strains were maintained on King's B medium agar plates (King et al., 1954) at $4^{\circ} \mathrm{C}$ before experimental use, and stored at $-80^{\circ} \mathrm{C}$ in cryotubes according to the manufactures' recommendations (Microbank; Prolab Diagnostic, Richmond Hill, Canada) for long term conservation. For utilization, P. putida BTP1 was grown on Casamino acids (CAA) medium ( $5 \mathrm{~g} / \mathrm{l} \mathrm{CAA}, 0.9 \mathrm{~g} / \mathrm{l}$ $\mathrm{K}_{2} \mathrm{HPO}_{4^{\prime}} 0.25 \mathrm{~g} / \mathrm{l} \mathrm{MgSO}$ and $15 \mathrm{~g} / \mathrm{l}$ agar) (Ongena et al., 2002) for $24 \mathrm{~h}$ at $30 \pm 1^{\circ} \mathrm{C}$. Bacillus subtilis strains were grown on 868 medium (20 g/l glucose, $10 \mathrm{~g} / \mathrm{l}$ peptone, $10 \mathrm{~g} / \mathrm{l}$ yeast and $15 \mathrm{~g} / \mathrm{l}$ agar) (Jacques et al., 1999), and incubated for $24 \mathrm{~h}$ at $30 \pm 1^{\circ} \mathrm{C}$ in the dark. Subsequently bacterial cells were collected and resuspended in $10 \mathrm{mM} \mathrm{MgSO}_{4}$ to a final density of $10^{8}$ colony-forming units (CFU) per $\mathrm{mL}$ before use.

\section{Fungal isolate and host genotypes}

After an extensive screening for more than fifteen years in the field and in our laboratory, isolates of $P$. graminea have been obtained from barley leaves showing leaf stripe symptoms in different regions of Syria. The P. graminea Syz strain (P.gSyz) was selected for use in this study based on morphological and physiological criteria (virulence). In specific, this strain had been proven to be the most virulent isolate to all barley genotypes available so far (Arabi and Jawhar, 2012a; Arabi and Jawhar, 2012b).

Strain P.gSyz was cultured on potato dextrose agar (PDA, DIFCO, Detroit, MI, USA) with $13 \mathrm{mg} / \mathrm{l}$ kanamycin sulphate and incubated for 10 days at $22 \pm 1^{\circ} \mathrm{C}$ in the dark to allow mycelia growth and sporulation. Two spring barley types [Arabi Abiad (landrace) and WI 2291(Yield improved cultivar)] and one winter type (Banteng) were chosen for their variable reaction to $P$. graminea ranging from being susceptible to being resistant to this pathogen (Table 1) (Arabi and Jawhar, 2012a; Arabi and Jawhar, 2012b). 
Table 1. Genotypes and main features of the barley cultivars used in this study.

\begin{tabular}{l|c|c|c|cc}
\hline \multirow{2}{*}{ Genotype } & \multirow{2}{*}{ Origin } & \multirow{2}{*}{ Row type $^{y}$} & \multirow{2}{*}{ Growth habit } & \multicolumn{2}{|c}{ Proportion of diseased leaves } \\
\cline { 5 - 6 } & & & & \% Diseases leaves & Disease development \\
\hline WI2291 & Australia & 2 & Spring barley & 96.67 & Up to flag leaf \\
Aarbi Abiad & Syria & 2 & Spring barley & 91.33 & Up to flag leaf \\
Banteng & Germany & 6 & Winter barley & 1.33 & first leaf \\
\hline
\end{tabular}

$\times$ Arabi and Jawhar, 2012(a)

y Arabi and Jawhar, 2012(b)

\section{Seed health test}

To determine the health status of the barley seeds used in this study, random seed samples (50 seeds) of each cultivar were taken from protected nursery germplasm, surface- sterilized in $5 \%$ sodium hypochlorite solution ( $\mathrm{NaOCl}$ ) for $5 \mathrm{~min}$, rinsed three times ( $5 \mathrm{~min}$ each) in sterile distilled water and dried between sterilized filter paper (Arabi et al., 2004). They were plated on Petri dishes containing PDA medium and incubated for $72 \mathrm{~h}$ at $23 \pm 1^{\circ} \mathrm{C}$ in the dark.

\section{Seed inoculation}

Seeds were surface-sterilized as previously described for the seed health test. Inoculation was carried out using the modified method of Hammouda (1986). Six hundred seeds of each cultivar were placed on an active 8-day-old mycelial culture of P.gSy3 growing on PDA medium in Petri dishes (50 seeds/ Petri dish) and incubated at $6^{\circ} \mathrm{C}$ for 14 days in the dark. As negative control, seeds were incubated on PDA medium without the fungus. To confirm artificial inoculation of the seeds by the fungus, seeds from the Petri dishes with the P.gSyz culture were randomly collected, surface- sterilized as described above, placed on PDA medium and incubated for $72 \mathrm{~h}$, at $23 \pm 1^{\circ} \mathrm{C}$; the seeds were then examined under a microscope for the presence of $P$. graminea.

\section{Field assay to assess resistance induced by rhizobacteria}

One-hundred and fifty inoculated (with $P$. graminea) and the same number of noninoculated seeds per cultivar (Arabi Abiad, WI2291 and Banteng) were soaked for 15 min in each bacterial strain suspension at a concentration of $10^{8} \mathrm{CFU} / \mathrm{ml}$ prior to sowing in the field. The trials were conducted at a site approximately $20 \mathrm{~km}$ west of Damas-

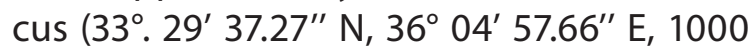
$\mathrm{m}$ altitude), under natural rain-fed conditions [about 200-250 mm growing season rainfall conditions (10 December - 30 May)]. Soil temperature was below $9^{\circ} \mathrm{C}$ in the two seasons (2013-2014). The experiments were conducted using a randomized complete block design with three replicates. Individual plots were $50 \times 50 \mathrm{~cm}$ with $1 \mathrm{~m}$ border. Each plot consisted of three rows, $25 \mathrm{~cm}$ apart with approximately 17 seeds sown per row. The experiment was designed to allow for sampling of individual plants grown from seeds treated as follows: 1) infection with $P$. graminea. 2) infection with $P$. graminea and soaking with one of the rhizobacterial strains. 3) soaking with one of the rhizobacterial strains. 4) No infection with P. graminea and soaking in buffer free from rhizobacteria. Soil fertilizers were drilled before sowing at a rate of $50 \mathrm{Kg} / \mathrm{ha}$ urea $(46 \% \mathrm{~N})$ and $27 \mathrm{Kg} /$ ha super phosphate $\left(33 \% \mathrm{P}_{2} \mathrm{O} 5\right)$.

\section{Disease rating}

In every field plot, infected (showing leaf stripe symptoms) and healthy plants were counted at the heading stage (GS50) (Zadoks et al., 1974). Plant resistance level was expressed as the incidence (I) of infection (number of plants with nonzero severity divided by the total number of plants in a plot) according to the scale described by Delogu et al. (1989). Severity (S) was recorded as the number of infected leaves per plant expressed as a percentage of the total number 
of leaves per plant. The data for I and S were analysed using analysis of variance (StudentNewman-Keuls test), applying the STAT-ITCF program (Beaux et al., 1988).

\section{0-kernel weight and yield determi- nation}

All infected and non-infected (negative control) plants of each plot were harvested at maturity. Grain yield and 1000-kernel weight (TKW) were determined on individual plants.

\section{In vitro antagonistic test}

$0.1 \mathrm{ml}$ of the suspension of one of the rhizobacterial strains under study $\left(10^{8} \mathrm{CFU} /\right.$ $\mathrm{ml}$ ) was transferred onto the center of: CCA Petri dishes for P. putida BTP1 and 868 Petri dishes for B. subtilis Bs2504, Bs2508 and Bs2500 stains, using sterile pipettes, and spread cross-wise by sterile glass spreader. Then mycelial discs of $2 \mathrm{~mm}$ diameter of $P$. graminea were cut using a sterile cork borer and placed at $2.5 \mathrm{~cm}$ from the center of the above CCA or 868 medium Petri dishes (4 discs / plate). Mycelial discs on the same media without bacteria were used as control. The cultures were incubated at room temperature $\left(25 \pm 1^{\circ} \mathrm{C}\right)$ in dark for 3-5 days and the diameter of fungal mycelium growth was measured. The experiments were repeated twice.

\section{Results and Discussion}

The rhizobacterial strains used in this study were in vitro tested for their antagonistic effects against the leaf stripe pathogen (P. graminea Sy3 strain). The four bacterial strains tested (P. putida BTP1 and B. subtilis Bs2500, Bs2504, and Bs2508) showed that there was no antagonistic effect against $P$. graminea compared with the control and were not able to inhibit pathogen growth. This result is supported by the work of Ongena et al. (1999) on P. putida BTP1, who found that this strain does not secrete any fungitoxic compounds in vitro on several media.

The effect of the four rhizobacterial strains on the response against $P$. graminea Sy3 of three barley cultivars grown under field conditions during two growing seasons (2013 and 2014) is presented in Table 2. Student-Newman-Keuls test on incidence and severity of barley leaf stripe disease values (expressed as percentage data) showed highly significant $(P<0.01)$ main and interaction effects of cultivar and rhizobacterial strain, with no significant differences among the replicates. This indicates that both cultivars and rhizobacterial strains differ in resistance and ability to induce resistance, respectively. Growing season had no effect on disease severity $(S)$, while had significant $(P<0.01)$ effect on incidence (I) (Table2). Differences $(P<0.01)$ in mean I and $S$ values were detected among rhizobacterium and cultivar treatment, with values being consistently higher in the diseased controls, in both seasons.

Compared with the diseased control, all bacterial strains had a positive effect in reducing I and S (main effect, Table 2 ). The two spring barley cultivars, Arabi Abiad and WI2291, were highly susceptible to barley leaf stripe disease, whereas, the six rows winter barley Banteng was more resistant with mean values for $S$ and I ranging between $18.6 \%$ and $23.8 \%$. Results of the two seasons were highly correlated $(r=0.98, P<0.001)$, indicating a similar performance trend for the cultivars and bacterial strains (Table 2). The P. putida BTP1and Bs2508 strains were in general the best in reducing both I and $S$, with mean I values 23.1 and $28 \%$ and mean $S$ values 31.8 and $35.1 \%$, respectively. Compared with the diseased control, P. putida BTP1 showed decreases of 57.5 and $49.4 \%$ for I and S, respectively, for the two seasons and the three cultivars.

There was a barley genotype (cultivar) difference in the response to strain treatment. The susceptible landrace cultivar Arabi Abiad exhibited a significant $(P<0.01)$ induction of resistance by Bs2508 and P. putida BTP1 treatment with disease incidence decreasing by 64.9 and $66 \%$, respectively (growing season 2013). The same trend for the Bs 2508 and BTP1 strains was observed in the grow- 


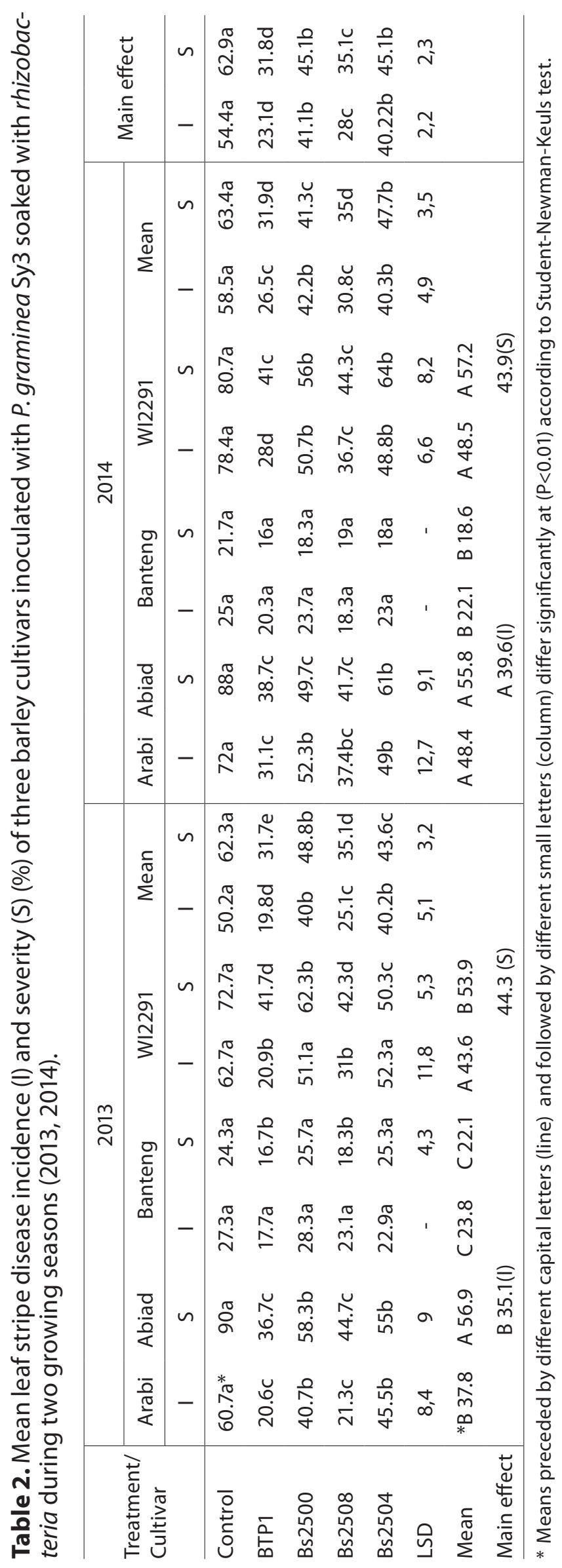


ing season 2014 with incidence of disease reduction of 48 and $56.8 \%$ respectively. The same behavior was noted for this cultivar in reducing plant severity 50.3 and $59.2 \%$ in 2013 and 52.6 and 56\% in 2014, respectively. Results obtained for WI2291 indicated the same trend as those for Arabi Abiad regarding both I and $S$ in the two growing seasons (Table 2). The resistant winter barley Banteng did not exhibit any significant increase in its resistance based on incidence or severity of barley leaf stripe disease for the two seasons, with the exception of a weak decrease in severity when the cultivar was subjected to $P$. putida BTP1 and B. subtilis Bs 2508 treatment in 2013.

The resulting resistance in our assays can be long lasting with disease reduction ranging from 0 (Banteng/Bs2500) to 66\% (Arabi Abiad/BTP1, Table 2), since induced resistance is a host genotype response, and its expression under field conditions is generally expected to be influenced by the environment. Walters et al. (2013) reported that understanding the impact of these influences on the expression of induced resistance is still poor. Host genotype is known to affect the expression of induced resistance ( $\mathrm{Re}$ sende et al., 2002; Tucci et al., 2011). Our results are in agreement with the results found by Walters et al. (2011b), that expression of induced resistance varied in spring barley varieties to Rhynchosporium commune. It may not be surprising that in our work the landrace Arabi Abiad was the most responsive cultivar in terms of induced disease resistance under all conditions. Arabi Abiad is characterized by lower yield level than the other spring cultivar (WI2291) and showed a high susceptibility in the control stage, meaning a high potential for an improvement of its resistance after rhizobacterial application. Along the same line, the lack of an induced resistance response in the winter cultivar Banteng should be attributed to its extremely high level of basal resistance in its genotype, which simply might not be improved any more. For a similar reason, cultivars expressing high basal resistance were less responsive to Benzothiadiazole than highly susceptible cultivars in soybean (Dann et al., 1998) and in barley (Walters et al., 2011a). Cordova-Campos et al. (2012) found that basal resistance to Pseudomonas syringae pathovars was significantly greater in wild accessions of bean Phaseolus vulgaris than in modern cultivars. In a recent work on barley, Molitor et al. (2011) demonstrated that following inoculation of powdery mildew infected plant with Piriformospora indi$c a$, there was a priming of powdery mildew defuse-associated genes at an early stage of the infection.

Most of previous work was applied in the field to plants either as foliar sprays or as root drench. Seed treatments can be particularly useful, since they can provide protection to very young plants during germination and shoot development, particularly in a systemic seed-borne disease such as barley leaf stripe, as during seed germination, the fungal hyphae begin intensive intercellular growth. In our work, the protection was significantly substantiated by the reduced $I$ and S. Priming of induced resistance by treating seeds would be of great value in agriculture, especially for crops that are likely to face pathogen attack early in their development, such as that of $P$. graminea.

The cultivars planted during the two growing seasons of this study varied in resistance to leaf stripe disease. However, a resistant cultivar may in fact have different resistance responses to the spread of the fungus within the infected plants, hence a wide range of severity values may be observed across cultivars for any given incidence value. It appears that differences in weather conditions during the two growing seasons, did not result in any different patterns in the I and $\mathrm{S}$ relationship. As shown in Table 3, the grain yield was not affected by rhizobacterial strains during the two growing seasons $(2013,2014)$, except in the susceptible landrace cultivar Arabi Abiad, whose grain yield was increased significantly $(P>0.01)$ by 48.7 and $33.5 \%$ using Bs 2504 and Bs2508 respectively. The 1000-Kernal weight of the three cultivars used in this study was not positively or negatively in- 
Table 3. Effect of rhizobacteria strains on grain yield (g/plant) of three barley cultivars inoculated with P. graminea Sy3 during two growing seasons $(2013,2014)$.

\begin{tabular}{|c|c|c|c|c|c|c|c|c|c|}
\hline \multirow{2}{*}{$\begin{array}{l}\text { Cultivar/ } \\
\text { Treatment }\end{array}$} & \multicolumn{4}{|c|}{2013} & \multicolumn{4}{|c|}{2014} & \multirow{2}{*}{ Main effect } \\
\hline & Arabi Abiad & Banteng & WI2291 & Mean & Arabi Abiad & Banteng & WI2291 & Mean & \\
\hline Control** & $4.60 c^{*}$ & $3.45 a$ & $6.27 a$ & $4.77 \mathrm{~b}$ & $4.20 a$ & $4.32 a$ & $7.52 a$ & $5.35 a$ & $4.9 \mathrm{~b}$ \\
\hline BTP1 & $4.85 c$ & $5.26 a$ & $7.09 a$ & $5.74 a$ & $4.81 a$ & $4.66 a$ & $7.78 a$ & $5.75 a$ & 5.69ab \\
\hline Bs 2500 & $5.22 \mathrm{bc}$ & $3.60 a$ & $7.21 \mathrm{a}$ & $5.34 a b$ & $4.82 a$ & $4.58 a$ & $7.26 a$ & $5.55 a$ & $5.34 a b$ \\
\hline Bs2508 & $6.14 a b$ & $3.94 a$ & $6.45 a$ & $5.51 \mathrm{ab}$ & $5.97 a$ & $5.66 a$ & $7.49 a$ & $6.06 a$ & $5.84 a$ \\
\hline Bs2504 & $6.84 a$ & $3.82 \mathrm{a}$ & $6.96 a$ & $5.79 a$ & $5.97 a$ & $4.44 a$ & $7.09 a$ & $5.72 a$ & $5.8 a$ \\
\hline LSD & 0,93 & - & - & 0,66 & - & - & - & - & 0,53 \\
\hline Mean & *B 5.48 & C 4.02 & A 6.80 & & B 5.09 & B 4.53 & A 7.44 & & \\
\hline Main effect & & A 5.43 & & & & A 5.69 & & & \\
\hline
\end{tabular}

* Means preceded by different capital letters (line) and followed by different small letters (column) differ significantly at $(P<0.01)$ according to Student-Newman-Keuls test.

**Infected with $P$. graminea Sy3.

fluenced by any of the rhizobacterial strains used (Table 4). Our results are in agreement with the work of Reglinski et al. (1994) on barley demonstrating that there was no effect of induced resistance on yield. The expression of resistance in barley to leaf stripe disease was not associated with an increase in grain yield and 1000-kernel weight. In general, there was a stability of these two traits. The data presented here suggest that either the plants possessed sufficient resources to support both growth and defense, or they use resources diverted from growth to defense. This phenomenon has been reported by several workers (Murray and Walters, 1992; Ziadi et al., 2001; Prats et al., 2002; Córdova-Campos et al., 2012). A number of hypotheses have been put forth to explain how plants reallocate resources during the induction of plant defenses and how induced resistance benefits the overall fitness of the plant relatively to constitutive defense mechanisms (Ahmad et al., 2010; Córdova-Campos et al., 2012).

In this context, it is interesting to raise the hypotheses of balance between plant growth and defense. For that purpose, experiments were conducted under the same resource-limiting conditions (200-250 mm rainfall during the two growing seasons) using the same design as for induced resis- tance. The experiment included the same three barley cultivars and the four rhizobacterial strains, without applying any pathogen. Analysis of variance on grain yield showed significant effects among cultivar, rhizobacterial strain and their interaction (Table 5). Growing season had no effect on grain yield. Compared with the control (free of $P$. graminea and rhizobacterial strains), all treatments with rhizobacterial strains had a positive effect on grain yield (main effect, Table 5). The Bs2508 and BTP1 strains had in general a positive effect on yield. Compared with the control, Bs2508 showed an increase of $29.5 \%$ for the two growing seasons and the three cultivars. Arabi Abiad exhibited significant $(P<0.01)$ increase of grain yield by using Bs2508, that reached $93.6 \%$ and $30.9 \%$ during 2013 and 2014 seasons, respectively. The winter barley cultivar Banteng did not exhibit any significant increase in yield during the two growing seasons.

The present study, on the one hand, showed that $P$. putida BTP1 and $B$. subtilis Bs2005, Bs2504, and Bs2508 strains, could not inhibit in vitro $P$. graminea growth (no direct antagonism between them). This observation is supported by the work of Ongena et al. (1999) on P. putida BTP1 in which the bacteria did not produce or secrete any fungitoxic compound. On the other hand, the 
Table 4. Effect of rhizobacteria strains on 1000- kernel weight $(\mathrm{g})$ of three barley cultivars inoculated with P. graminea Sy3 during two growing seasons $(2013,2014)$.

\begin{tabular}{l|cccc|ccccc|c}
\hline \multirow{2}{*}{$\begin{array}{l}\text { Cultivar/ } \\
\text { Treatment }\end{array}$} & \multicolumn{5}{|c|}{2013} & \multicolumn{4}{c|}{2014} & \multirow{2}{*}{ Main effect } \\
\cline { 2 - 9 } & Arabi Abiad & Banteng & WI2291 & Mean & Arabi Abiad Banteng & WI2291 & Mean & \\
\hline Control & $49.00 a *$ & $27.00 a$ & $49.33 a$ & $41.78 a$ & $44.38 a$ & $24.65 a$ & $43.98 a$ & $37.67 a$ & $39.74 a$ \\
BTP1 & $49.07 a$ & $28.33 a$ & $49.67 a$ & $42.33 a$ & $46.46 a$ & $24.97 a$ & $44.4 a$ & $38.51 a$ & $40.42 a$ \\
Bs2500 & $47.67 a$ & $26.67 a$ & $54.00 a$ & $42.78 a$ & $46.49 a$ & $25.37 a$ & $43.31 a$ & $38.39 a$ & $40.58 a$ \\
Bs2508 & $46.67 a$ & $26.67 a$ & $51.00 a$ & $41.41 a$ & $45.18 a$ & $24.06 a$ & $43.19 a$ & $37.4 a$ & $39.42 a$ \\
Bs2504 & $47.83 a$ & $26.67 a$ & $50.00 a$ & $41.11 a$ & $43.95 a$ & $23.65 a$ & $42.09 a$ & $36.57 a$ & $38.84 a$ \\
Mean & $*$ B 47.8 & C 27.07 & A 50.80 & A 45.24 & C 24.5 & B 43.33 & & \\
Main effect & & A 41.89 & & & & B 37.71 & & & \\
\hline
\end{tabular}

* Means preceded by different capital letters (line) and followed by different small letters (column) differ significantly at $(P<0.01)$ according to Student-Newman-Keuls test.

Table 5. Effect of rhizobacteria strains on grain yield ( $\mathrm{g} / \mathrm{plant}$ ) of three barley cultivars during two growing seasons $(2013,2014)$.

\begin{tabular}{|c|c|c|c|c|c|c|c|c|c|}
\hline \multirow{2}{*}{$\begin{array}{l}\text { Cultivar/ } \\
\text { Treatment }\end{array}$} & \multicolumn{4}{|c|}{2013} & \multicolumn{4}{|c|}{2014} & \multirow{2}{*}{ Main effect } \\
\hline & Arabi Abiad & Banteng & WI2291 & Mean & Arabi Abiad & Banteng & WI2291 & Mean & \\
\hline Control** & $4.10 d^{*}$ & $4.12 \mathrm{a}$ & $5.67 \mathrm{~b}$ & $4.64 c$ & $5.27 b$ & $3.70 a$ & $6.23 b$ & $5.07 d$ & $4.85 c$ \\
\hline BTP1 & $5.23 c$ & $4.43 a$ & $7.30 a$ & $5.66 \mathrm{~b}$ & $6.49 a$ & $3.96 a$ & $7.20 a$ & 5.88ab & $5.77 b$ \\
\hline Bs2500 & $6.82 a$ & $3.84 a$ & $7.00 a$ & 5.89ab & $5.20 \mathrm{~b}$ & $4.03 a$ & $7.07 a$ & $5.43 c$ & $5.66 \mathrm{~b}$ \\
\hline Bs2508 & $7.94 a$ & $4.27 a$ & $6.80 a$ & $6.33 a$ & $6.90 a$ & $4.47 a$ & $7.33 a$ & $6.23 a$ & $6.28 a$ \\
\hline Bs2504 & $6.67 b$ & $3.97 a$ & $6.97 a$ & 5.87ab & $6.43 a$ & $3.93 a$ & $6.50 \mathrm{~b}$ & $5.62 b c$ & $5.74 b$ \\
\hline LSD & 1,12 & - & 0,88 & 0,46 & 0,72 & - & 0,75 & 0,36 & 0,29 \\
\hline Mean & *B 6.15 & C 4.13 & A 6.75 & & B 6.06 & C 4.02 & A 6.87 & & \\
\hline Main effect & & A 5.68 & & & & A 5.65 & & & \\
\hline
\end{tabular}

* Means preceded by different capital letters (line) and followed by different small letters (column) differ significantly at $(\mathrm{P}<0.01)$ according to Student-Newman-Keuls test.

**Free of P. graminea Sy3 and rhizobacteria.

fungal hyphae survive in the kernel between the paranchymatical cells in the hull, while cells of the bacterial strains were on seed surface, i.e. there was no contact between them and they were spatially separated. All bacterial strains used in this study have reduced the incidence and severity of barley leaf stripe disease caused by $P$. gramin$e a$, with effect more pronounced when $P$. putida BTP1 and Bs2508 were used. Adam et al. (2008) demonstrated that tomato bacterized-plants with $P$. putida BTP1 showed elicited systemic resistance, by means of li- poxygenase (LOX) pathway related defense. Ongena et al. (2005) provided evidence that an $\mathrm{N}$-alkylated Benzylamine derivative (NABD), isolated from P. putida BTP1, elicits resistance in bean against Botrytis cinerea. Mariutto et al. (2014) reported that induced systemic resistance (ISR) stimulation in tomato by P. putida BTP1 was associated with induction of the first enzyme of the oxylipin pathway, the lipoxygenase (LOX). The oxylipin pathway was found to be differentially regulated (Mariutto et al. 2014). Thus, NABD and other elicitors produced by P. putida 
BTP1 may be active on different plant species (monocots and dicots) for the control of various pathogens.

In our study, the Bs2504 and Bs2500 strains induced resistance in barley against $P$. graminea but not as high as that induced by Bs 2508 strain. Our results are in agreement with the work of Ongena et al. (2007) on tomato and bean, who found that Bs2500 and Bs2504 produce surfactin and fengycin, respectively, whereas Bs2508 produces both of these compounds; they suggested that these compounds can be perceived by plant cells as signals to initiate defense mechanisms. In future work we will devote time to identify and quantify compounds essential for the ISR-eliciting activity of the above rhizobacterial strains.

The authors thank the Director General of AECS and the Head of Biotechnology Department for their help throughout the period of this research. We thank Prof. P. Thonart and Dr. $M$. Ongena of the University of Liège, who provided us with the P. putida BTP1 and Bacillus subtilis Bs2508, Bs2504, and Bs2500 strains.

\section{Literature cited}

Adam, A., Ongena, M., Duby, F., Dommes, J. and Thonart, P. 2008. Systemic resistance and lipoxygenase-related defence response induced in tomato by Pseudomonas putida strain BTP1. BMC Plant Biology, 8: 113.

Ahmad, S., Gordon-Weeks, R., Pickett, J. and Ton, J. 2010. Natural variation in priming of basal resistance: from evolutionary origin to agricultural exploitation. Molecular Plant Pathology, 11: 817-827.

Arabi, M.I.E. and Jawhar, M. 2012a. Pathogenic groups identified among isolates of Pyrenophora graminea. Journal of Plant Biology Research, 1(2): 93-100.

Arabi, M.I.E. and Jawhar, M. 2012b. Alternative measure for assessing incidence of leaf stripe on barley. Plant Pathology Journal, 28(2): 212-215.

Arabi, M.I.E., Jawhar, M., Al-Safadi, B. and MirAli, N. 2004. Yield responses of barley to leaf stripe (Pyrenophora graminea) under experimental conditions in southern Syria. Journal of Pathology, 152: 519-523.

Arru, L., Niks, R.E., Lindhout, P., Vale, G., Francia, G. and Pecchioni, N. 2002. Genomic region determining resistance to leaf stripe (Pyrenophora graminea) in barley. Genome, 45: 460-466.

Bakker, P.A.H.M., Pieterse, C.M.J. and van Loon, L.C. 2007. Induced Systemic Resistance by Fluorescent Pseudomonas spp. Phytopathology, 97(2): 239-243.

Beaux, M.F., Gouet, H., Gouet, J.P., Morleghem, P., Philippaue, G., Tranchefort, J. and Vemeau, M. 1988. Manuel d'utilisation STAT-ITCF version N"4, Institute Techniques des Céréales et des Fourrages (ITCF).

Choudhary, D.K. and Johri, B.N. 2009. Interaction of Bacillus spp. and plant-with special reference to induced systemic resistance (ISR). Microbiological Research, 164(5): 493-513.

Córdova-Campos, O., Adame-Álvarez, R.M., AcostaGallegos, J.A. and Heil, M. 2012. Domestication affected the basal and induced disease resistance in common bean (Phaseolus vulgaris). European Journal of Plant Pathology, 134: 367-379.

Dann, E., Diers, B., Byrum, J. and Hammerschmidt, R. 1998. Effect of treating soybean with 2,6-dichloroisonicotinic acid (INA) and benzothiadiazole (BTH) on seed yields and the level of disease caused by Sclerotinia sclerotiorum in field and greenhouse studies. European Journal of Plant Pathology, 104: 271-278.

De Vleesschauwer, D., Cornelis, P. and Höfte, M. 2006. Redox-active pyocyanin secreted by Pseudomonas aeruginosa 7NSK2 triggers systemic resistance to Magnaporthe grisea but enhances Rhizoctonia solani susceptibility in rice. Molecular Plant-Microbe Interactions, 19: 1406-1419.

De Vleesschauwer, D. and Höfte, M. 2009. Rhizobacteria-induced systemic resistance. Advances in Botanical Research, 51: 223-281.

Delogu, G.A., Porta-Poglia, A. and Vannacci, G. 1989. Resistance of winter barley varieties subjected to natural inoculum of Pyrenophora graminea. Journal of Genetics and Breeding, 43: 61-66.

Haas, D. and Défago, G.2005. Biological control of soilborne pathogens by fluorescent pseudomonads. Nature Reviews Microbiology, 3: 307-319.

Haegi, A., Bonardi, V., Dall-Aglo, E., Glissant, D., Tumino, G., Collins, N.C., Bulgarelli, D., Infantino, A., Stanca, A.M., Delledonne, M. and Vale, G. 2008. Histological and molecular analysis of Rdg2a barley resistance to leaf stripe. Molecular Plant Pathology, 9: 463-478.

Haegi, A. and Porta-Puglia, A. 1995. Purification and partial characterization of a toxic compound produced by Pyrenophora graminea. Physiological and Molecular Plant Pathology, 46: 429-444.

Hammouda, A.M. 1986. Modified technique for inoculation in leaf stripe of barley. Acta Phytopathologica et Entomologica Hungarica, 21: 255-259.

Hammouda, A.M. 1988. Variability of Drechshera graminea the cause fungus of leaf stripe of bar- 
ley. Acta Phytopathologica Academiae Scientiarum Hungaricae, 23: 73-80.

Jacques, P., Hbid, C., Destain, J., Razafindralambo, H., Paquot, M., Pauw, E.D. and Thonart, P. 1999. Optimization of Biosurfactant Lipopeptide Production from Bacillus subtilis S499 by PlackettBurman Design. Applied Biochemistry and Biotechnology, 77-79: 223-233.

Mariutto, M., Fauconnier, M.L., Ongena, M., Laloux, M., Wathelet, J.P., du Jardin, P., Thonart, P. and Dommes, J. 2014. Reprogramming of fatty acid and oxylipin synthesis in rhizobacteria-induced systemic resistance in tomato. Plant Molecular Biology, 84(4-5): 455-467.

Mathre, D.E. 1997. Compendium of Barley Diseases. $2^{\text {nd }}$ ed. St Paul Minnesota. American Phytopathologica Society Press. pp. 90.

Molitor, A., Zaijc, D., Voll, L.M., Pons-Kuhnemann, J., Samans, B., Kogel, K.H. and Waller, F. 2011. Barley leaf transcriptome and metabolite analysis reveals new aspects of compatibility and Piriformospora indica-mediated systemic induced resistance to powdery mildew. Molecular PlantMicrobe Interactions, 24: 1427-1439.

Murray, D.C. and Walters, D.R. 1992. Increased photosynthesis and resistance to rust infection in upper, uninfected leaves of rusted broad bean (Vicia faba L.). New Phytologist, 120: 235-242.

Ongena, M., Daayf, F., Jacques, P., Thonart, P., Benhamou, N., Paulitz, T.C., Cornélis, P., Koedam, N. and Bélanger, R.R. 1999. Protection of cucumber against Pythium root rot by fluorescent Pseudomonads: Predominant role of induced resistance over siderophores and antibiosis. Plant Pathology, 48: 66-76.

Ongena, M., Duby, F., Rossignol, F., Fauconnier, M.L., Dommes, J. and Thonart, P. 2004. Stimulation of the lipoxygenase pathway is associated with systemic resistance induced in bean by a nonpathogenic Pseudomonas strain. Molecular Plant-Microbe Interactions, 17(9): 1009-1018.

Ongena, M., Jacques, P., Delfosse, P. and Thonart, P. 2002. Unusual traits of the pyoverdin-mediated iron acquisition system in Pseudomonas putida strain BTP1. Biometals, 15: 1-13.

Ongena, M., Jourdan, E., Adam, A., Paquot, M., Brans, A., Joris, B., Arpigny, J.-L. and Thonart, P. 2007. Surfactin and fengycin lipopeptides of Bacillus subtilis as elicitors of induced systemic resistance in plants. Environmental Microbiology, 9(4): 1084-1090.

Ongena, M., Jourdan, E., Schäfer, M., Kech, C., Budzikiewicz, H., Luxen, A. and Thonart, P. 2005. Isolation of an $\mathrm{N}$-alkylated Benzylamine Derivative from Pseudomonas putida BTP1 as Elicitor of Induced Systemic Resistance in Bean. Molecular Plant-Microbe Interactions, 6: 562-569.

Pinedra, A., Zheng, S., van Loon, J., Pieterse, C. and Dicke, M. 2010. Helping plants to deal with in- sects: the rol of benefical soil-borne microbes. Trends in Plant Science, 15: 507-514.

Porta-Puglia, A., Delogu, G. and Vannacci, G. 1986. Pyrenophora graminea on winter barley seed effect on disease incidence and yield losses. Phytopathology, 117: 26-33.

Prats, E., Rubiales, D. and Jorrin, J. 2002. Acibenzolar-S-methyl-induced resistance to sunflower rust (Puccinia helianthi) is associated with an enhancement of coumarins on foliar surface. Physiological and Molecular Plant Pathology, 60: 155162.

Ramamoorthy, V., Viswanathan, R., Raguchander, T., Prakasam, V. and Samiyappan, R. 2001. Induction of systemic resistance by plant growth promoting rhizobacteria in crop plants against pests and diseases. Crop Protection, 20(1): 1-11.

Reglinski, T., Newton, A.C. and Lyon, G.D. 1994. Assessment of the ability of yeast-derived elicitors to control powdery mildew in the field. Journal of Plant Diseases and Protection, 101: 1-10.

Reglinski, T. and Walters, D. 2009. Induced resistance for plant disease control. In Disease control in crops: Biological and environmentally friendly approaches (ed D. Walters), Wiley-Blackwell, Oxford, UK..

Resende, M.L.V., Nojosa, G.B.A., Cavalcanti, L.S., Aguilar, M.A.G., Silva, L.H.C.P., Perez, J.O., Andrade, G.C.G., Carvalho, G.A. and Castro, R.M. 2002. Induction of resistance in cocoa against Crinipellis perniciosa and Verticillium dahlia by acibenzolarS-methyl (ASM). Plant Pathology, 51: 621-628.

Sharma, A. and Johri, B.N. 2003. Growth promoting influence of siderophor- producing pseudomonas strains GRP3A and PRS9 in maize (Zea mays L.) Under iron limiting conditions. Microbiological Research, 158(3): 243-248.

Tekauz, A. and Chiko, A.W. 1980. Leaf stripe of barley caused by Pyrenophora graminea: Occurrence in Canada and comparisons with barley stripe mosaic. Canadian Journal of Plant Pathology, 2: 152-158.

Tucci, M., Ruocco, M., De Masi, L., De Palma, M. and Lorito, M. 2011. The beneficial effect of Trichoderma spp. on tomato is modulated by plant genotype. Molecular Plant Pathology, 12: 341354.

Van Loon, L.C. 2007. Plant responses to plant growthpromoting rhizobacteria. European Journal of Plant Pathology, 119: 243-254.

Van Wees, S.C.M., van der Ent, S. and Pieterse, C. 2008. Plant immun responses triggered by benefical microbes. Current Opinion in Plant Biology, 11: 443-448.

Vlot, A.C., Klesig, D.F. and Park, S.W. 2008. Systemic acquired resistance: the elusive signal(s). Current Opinion in Plant Biology, 11: 436-442.

Walters, D.R., Havis, N.D., Paterson, L., Taylor, J. and Walsh, D.J. 2011a. Cultivar effects on the expres- 
sion of induced resistance in spring barley. Plant Disease, 95: 595-600.

Walters, D.R., Paterson, L., Sablou, C. and Walsh, D.J. 2011b. Existing infection with Rhynchosporium secalis compromises the ability of barley to express induced resistance. European Journal of Plant Pathology, 130: 73-82.

Walters, D.R., Ratsep, J. and Havis, N.D. 2013. Controlling crop disease using induced resistance: challenges for the future. Journal of Experimental Botany, 64(5): 1263-1280.

Zadoks, J.C., Chang, T.T. and Konzak, C.F. 1974. A decimal code for the growth stages of cereals. Weed Research, 14: 415-421.
Ziadi, S., Barbedette, S., Godard, J.F., Monot, C., Le Corre, D. and Silue, D. 2001. Production of pathogenesis-related proteins in the cauliflower (Brassica oleracea var. botrytis)-downy mildew (Peronospora parasitica) pathosystem treated with acibenzolar-S-methyl. Plant Pathology, 50: 579-586.

Received: 29 August 2016; Accepted: 16 January 2017

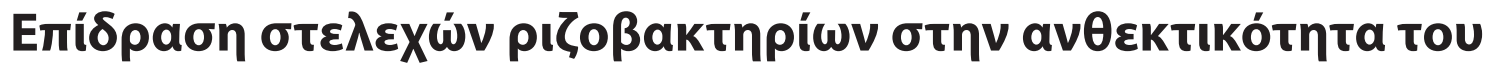

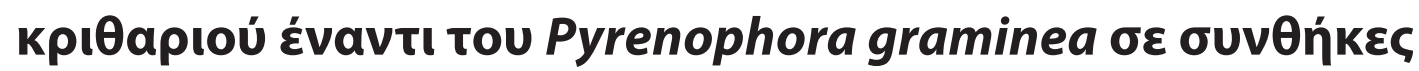 appoú
}

\author{
A. Adam, M.I.E. Arabi, I. Idris kaı E. Al-Shehadah
}

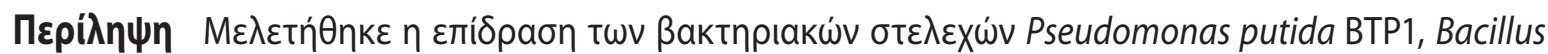

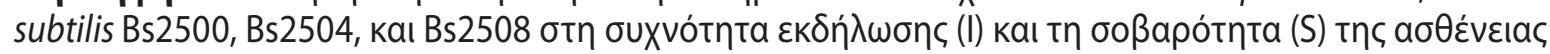

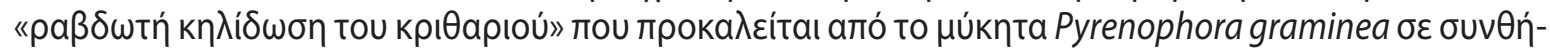

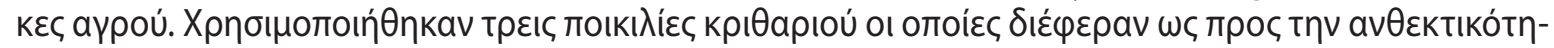

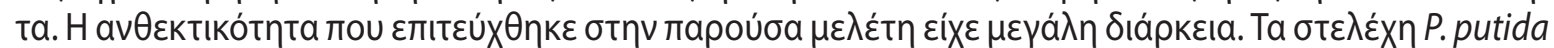

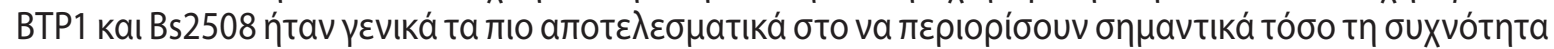

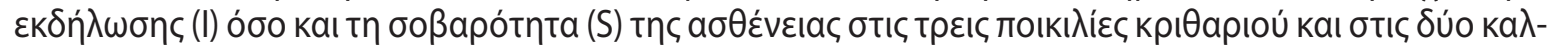

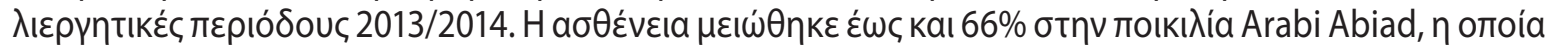

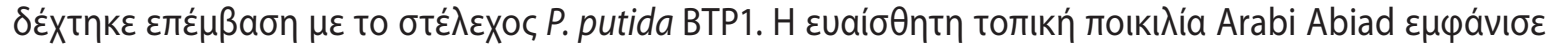

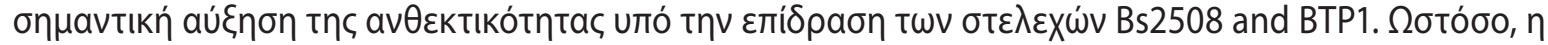

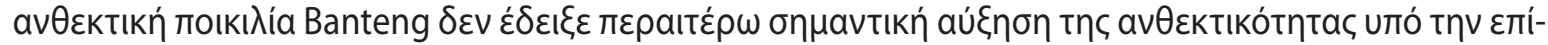

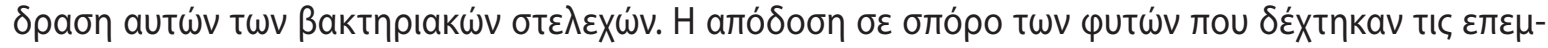

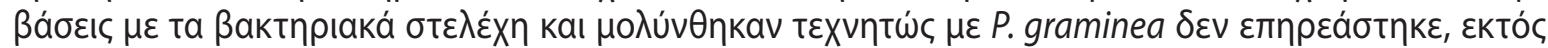

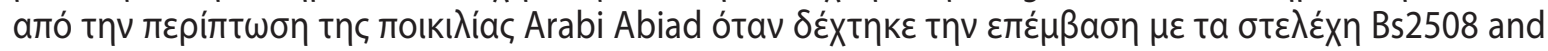

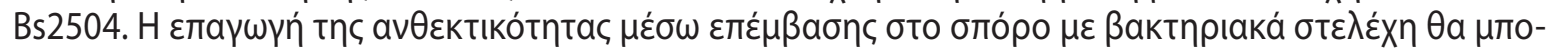

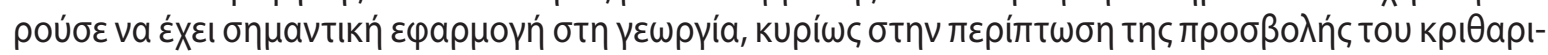

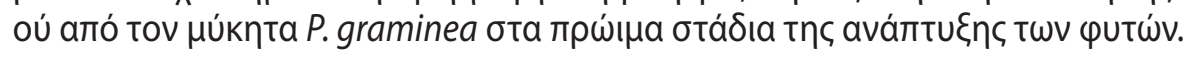

Hellenic Plant Protection Journal 10: 35-45, 2017 